\title{
Recombinant lactobacilli expressing linoleic acid isomerase can modulate the fatty acid composition of host adipose tissue in mice
}

\author{
Correspondence \\ Catherine Stanton \\ catherine.stanton@teagasc.ie
}

Received 7 July 2010

Revised 12 November 2010

Accepted 19 November 2010

\author{
Eva Rosberg-Cody, ${ }^{1,2,3}$ Catherine Stanton, ${ }^{1,3}$ Liam O'Mahony, ${ }^{1}$ \\ Rebecca Wall, ${ }^{1}$ Fergus Shanahan, ${ }^{1}$ Eamonn M. Quigley, ${ }^{1}$ \\ Gerald F. Fitzgerald ${ }^{1,2}$ and R. Paul Ross ${ }^{1,3}$ \\ ${ }^{1}$ Alimentary Pharmabiotic Centre (APC), Cork, Ireland \\ ${ }^{2}$ Department of Microbiology, University College Cork, National University of Ireland, Co. Cork, \\ Ireland \\ ${ }^{3}$ Teagasc Moorepark Food Research Centre, Fermoy, Co. Cork, Ireland
}

\section{INTRODUCTION}

Evidence is emerging to support the concept that the enteric microbiota can exert profound effects on human health and disease, involving complex host-bacteria interactions that are as yet poorly understood. The gut microbiota is important to the host with regard to metabolic functions, providing nutrients and conferring an ability to resist bacterial infections (Marchesi \& Shanahan, 2007; Wilks, 2007), as well as playing a dominant role in the education of the intestinal mucosal immune responses. Furthermore, the enteric microbiota has been shown to exert effects on disease processes outside the gut, including an impact on obesity and non-alcoholic fatty liver disease (Dumas et al., 2006; Marchesi \& Shanahan, 2007).

Abbreviations: CLA, conjugated linoleic acid; FAME, fatty acid methyl ester; PAl, Propionibacterium acnes isomerase.
Conjugated linoleic acid (CLA) is a beneficial bacterial metabolite formed via microbial isomerization of linoleic acid. CLA is a collective term describing different isomers of linoleic acid with conjugated double bonds, the cis-9, trans-11 $(c 9, t 11)$ CLA isomer being the most abundant form and the $110, c 12$ CLA isomer accounting for $~ 1 \%$ of total milk fat CLA (Jensen, 2002). It has been reported that t10, c12 CLA is the most potent isomer in terms of potential to prevent cell proliferation and induce apoptosis in cancer cells (Cho et al., 2005, 2006; Kim et al., 2002a; Lee et al., 2006b; Ochoa et al., 2004). t10, c12 CLA is also associated with decreased body fat and increased lean body mass in various animal species, such as mice (Park et al., 1997), chickens (Cherian et al., 2005), rats (Yamasaki et al., 2003), hamsters (Navarro et al., 2006), pigs (Ostrowska et al., 1999) and, to some extent, humans (Blankson et al., 2000; Mougios et al., 2001; Risérus et al., 2001; Smedman \& Vessby, 2001; Thom et al., 2001). Commensal Bifidobacterium and Lactobacillus species from the mammalian gastrointestinal 
tract have been shown to produce CLA in vitro (Barrett et al., 2007; Coakley et al., 2003; Rosberg-Cody et al., 2004). The majority of these studies have demonstrated production of c9, t11 CLA from linoleic acid, while only a few bacterial species have been reported to produce $t 10, c 12$ CLA, i.e. Propionibacterium acnes isolated from mouse caecum (Verhulst et al., 1987), the rumen bacterium Megasphaera elsdenii (Kim et al., 2002b) and the human-derived Lactobacillus rhamnosus PL60 and Lactobacillus plantarum PL62 (Lee et al., 2006a; Lee et al., 2007). However, only a few studies have established CLA production in vivo following ingestion of a CLA-producing bacterium. For example, the in vivo production of $t 10, c 12$ CLA by Lactobacillus rhamnosus PL60 and Lactobacillus plantarum PL62 was reported (Lee et al., 2006a, 2007), and we recently demonstrated that feeding different animal species a $c 9, t 11$ CLA-producing Bifidobacterium strain of human origin (Bifidobacterium breve NCIMB 702258), in combination with dietary linoleic acid, resulted in modulation of the fatty acid composition of the host, including significantly elevated concentrations of $c 9$, t11 CLA in the liver (Wall et al., 2009).

The enzyme Propionibacterium acnes isomerase (PAI) is responsible for conversion of linoleic acid to the $t 10, c 12$ CLA isomer and has previously been expressed in bacteria, yeast and tobacco seeds (Hornung et al., 2005). We have successfully cloned and overexpressed PAI in Lactococcus lactis, resulting in conversion rates of $>50 \%$ of linoleic acid to t10, c12 CLA (Rosberg-Cody et al., 2007). Moreover, when the microbially derived t10, c12 CLA was incubated with SW480 colon cancer cells for 5 days, cell viability was decreased by $92 \%$ (Rosberg-Cody et al., 2007). The objective of this study was to investigate whether a recombinant Lactobacillus paracasei NFBC 338 (Lb338), expressing the gene encoding PAI, would result in elevated tissue concentrations of $t 10, c 12$ CLA in vivo.

\section{METHODS}

Cultures and media. The probiotic strain Lactobacillus paracasei NFBC 338 (Lb338) was previously isolated from the human gastrointestinal tract, and obtained from University College Cork, Ireland, under a restricted materials transfer agreement. Lb338 was routinely cultured overnight $(\sim 17 \mathrm{~h})$ in de Man-Rogosa-Sharpe (MRS) broth (Oxoid) and incubated at $37{ }^{\circ} \mathrm{C}$ under anaerobic conditions using anaerobic jars containing Anaerocult A gas packs (Merck). Lb338 harbouring the vector pMSP3535 was routinely cultured with erythromycin $\left(10 \mu \mathrm{g} \mathrm{ml}^{-1}\right.$; Sigma) as a selective marker.

DNA manipulation. The $1278 \mathrm{bp}$ coPAI gene (codon-optimized Propionibacterium acnes isomerase in a plant vector; BASF), encoding the linoleic acid isomerase from $P$. acnes (Hornung et al., 2005), was amplified and cloned into the nisin-inducible lactococcal plasmid pNZ8048 (containing the $\mathrm{P}_{\text {nis }}$ promoter) as described previously (Rosberg-Cody et al., 2007). The coPAI gene was excised from pNZ8048-coPAI using PstI and XbaI restriction enzymes and ligated into the same sites of the Lactobacillus nisin-inducible plasmid pMSP3535 (Bryan et al., 2000), as described by the supplier (New England Biolabs), resulting in the construct pEcoPAIL (Fig. 1). The recombinant plasmid was double-digested with the same enzymes to

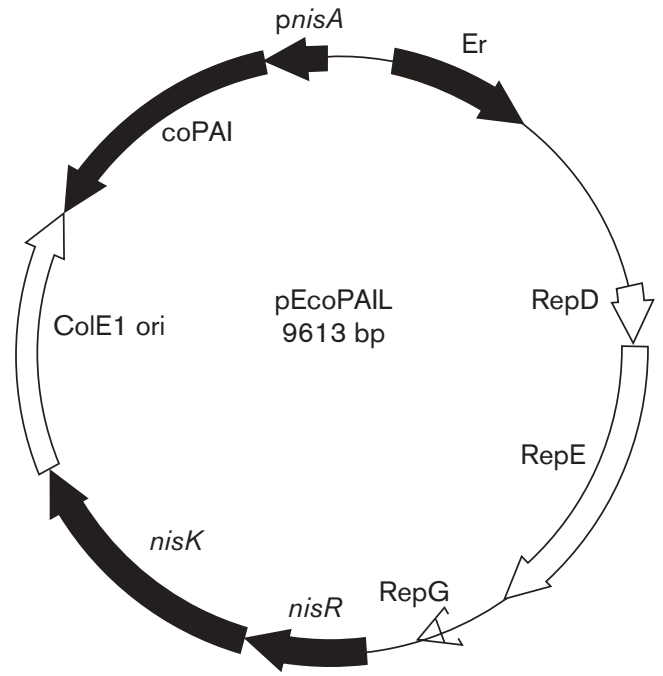

Fig. 1. Plasmid construct pEcoPAlL used to transform $L b$. paracasei NFBC 338 (Lb338). 'coPAl' denotes the codonoptimized $P$. acnes isomerase gene ( $t 10, c 12$ CLA isomerase).

verify the correct clone and subsequently electroporated into Lb338. Electrocompetent Lb338 cells were prepared using $3.5 \times$ SMEB (1 M sucrose, $3.5 \mathrm{mM} \mathrm{MgCl}_{2}$ ), as described by Luchansky et al. (1988). Sequence analysis was performed using DNASTAR software. The Qiagen Plasmid Mini kit was used to isolate plasmid DNA from Lb338 with one minor modification: $40 \mathrm{mg}$ lysozyme $\mathrm{ml}^{-1}$ was added to buffer $\mathrm{P} 1$ and incubated for $2 \mathrm{~h}$ at $37^{\circ} \mathrm{C}$. PCR products were purified using a Qiaquick PCR Purification kit (Qiagen).

In vitro conversion of $\boldsymbol{t} 10, \mathbf{c 1 2}$ CLA by recombinant lactobacilli. The recombinant Lb338 was assessed for its ability to convert free linoleic acid $\left(0.5 \mathrm{mg} \mathrm{ml}^{-1}\right.$, Sigma) to $t 10, c 12$ CLA as follows. A $1 \%$ $(\mathrm{v} / \mathrm{v})$ inoculum of an overnight culture was transferred to $10 \mathrm{ml}$ broth and incubated until the $\mathrm{OD}_{600}$ reached $\sim 0.5$. The culture was then induced with $50 \mathrm{ng}$ nisin $\mathrm{ml}^{-1}$ (Sigma) (sterile-filtered through a $45 \mu \mathrm{m}$ filter) and linoleic acid was added prior to further incubation for $48 \mathrm{~h}$, after which the culture was centrifuged ( $4345 \mathrm{~g}$ for $15 \mathrm{~min}$ ). Fatty acids were extracted from the supernatant and cell pellets, followed by methylation and analysis by GLC as previously described (Coakley et al., 2003).

Preparation and administration of the probiotic cultures. Lb338 was initially grown in MRS broth, as described above. The culture was centrifuged (7000 $\mathrm{g}$ for $15 \mathrm{~min}$ at $4{ }^{\circ} \mathrm{C}$; Sorvall RC5B Plus, SLA-3000 rotor), and the pellet was washed twice in PBS (Sigma) and resuspended at $1 \times 10^{10} \mathrm{cells}^{-1}$ in $15 \%(\mathrm{w} / \mathrm{v})$ trehalose (Sigma) in distilled $\mathrm{H}_{2} \mathrm{O}$. One-millilitre aliquots were dispensed into $2 \mathrm{ml}$ vials and freeze-dried using a $24 \mathrm{~h}$ programme (freeze temperature $-40{ }^{\circ} \mathrm{C}$, condenser set point -60 , vacuum set point $600 \mathrm{mTorr}$ ). Each mouse that received live probiotic culture was administered approximately $1 \times 10^{9}$ live micro-organisms per day. This was achieved by resuspending appropriate quantities of freeze-dried powder in the water that the mice consumed ad libitum.

Animals and dietary treatments. Male $B A L B / c$ mice were purchased from Harlan at 8 weeks of age and were fed ad libitum with standard nonpurified CRM(P) diet (Special Diets Services) with free access to water at all times. The standard diet had the following 
nutrient composition: nitrogen-free extract $(57.39 \%)$, crude protein $(18.35 \%)$, moisture $(10 \%)$, ash $(6.27 \%)$, crude fibre $(4.23 \%)$ and crude oil $(3.36 \%)$, which consisted of saturated fatty acids [lauric acid $(\mathrm{C} 12: 0,0.03 \%)$, myristic acid $(\mathrm{C} 14: 0,0.14 \%)$, palmitic acid $(\mathrm{C} 16: 0,0.33 \%)$ and stearic acid $(\mathrm{C} 18: 0,0.06 \%)]$, monounsaturated fatty acids [myristoleic acid (C14:1, 0.02\%), palmitoleic acid (C16:1, $10 \%)$ and oleic acid $(\mathrm{C} 18: 1,0.87 \%)]$ and polyunsaturated fatty acids [linoleic acid (C18:2n-6, $0.96 \%)$, linolenic acid (C18:3n-3, $0.11 \%)$ and arachidonic acid (C20:4n-6, 0.11\%)]. t10, c12 CLA was not detected in the diet. For linoleic acid treatment (added as trilinolein, with linoleic acid being the only fatty acid; Larodan Fine Chemicals), a powdered diet [milled standard non-purified CRM $(\mathrm{P})$ pellets] blended with the fatty acid was administered to each animal daily to yield approximately $180 \mathrm{mg}$ linoleic acid per day. The mice would consume this diet within a few minutes. Mice were individually caged and exposed to a $12 \mathrm{~h}$ light/dark cycle, maintained at a constant temperature of $25^{\circ} \mathrm{C}$.

All laboratory animal experiments were performed according to the guidelines for the care and use of laboratory animals approved by the Department of Health and Children of the Irish Government. One week after arrival, mice were divided into three groups for different dietary treatments. Group A $(n=8)$ received a linoleic-acid-supplemented diet $(2 \%, w / w$, Larodan Fine Chemicals) and approximately $1 \times 10^{9}$ live $t 10, c 12$ CLA-producing Lb338 (carrying the plasmid construct pEcoPAIL) per day. The probiotic culture was administered by resuspending appropriate quantities of freeze-dried powder in the water that the mice consumed. Group B $(n=8)$ received the linoleicacid-supplemented diet $(2 \%, \mathrm{w} / \mathrm{w})$ in combination with approximately $1 \times 10^{9}$ live non-CLA-producing Lb338 (carrying the empty plasmid pMSP3535) per day. Group C $(n=5)$ received a linoleic-acidsupplemented diet $(2 \%, \mathrm{w} / \mathrm{w})$ and placebo freeze-dried powder $\left(15 \%, w / v\right.$, trehalose in distilled $\left.\mathrm{H}_{2} \mathrm{O}\right)$. After 8 weeks on the experimental diets, the mice were sacrificed by cervical dislocation, and tissues were removed, blotted dry on filter paper, weighed and frozen in liquid nitrogen. All samples were stored at $-80{ }^{\circ} \mathrm{C}$ until processed.

Microbial analysis. Microbial analysis of faecal samples collected from all groups every 2 weeks involved enumeration of Lb338 by pour-plating serial dilutions onto MRS agar supplemented with erythromycin $\left(10 \mu \mathrm{g} \mathrm{m}{ }^{-1}\right.$, Sigma). Agar plates were incubated anaerobically for $72 \mathrm{~h}$ at $37{ }^{\circ} \mathrm{C}$. Anaerobic environments were created using $\mathrm{CO}_{2}$-generating kits (Anaerocult $\mathrm{A}$ ) in sealed gas jars.

Lipid extraction and fatty acid analysis. Lipids were extracted with chloroform/methanol $(2: 1, \mathrm{v} / \mathrm{v})$ according to the method of Folch et al. (1957). Fatty acid methyl esters (FAMEs) were prepared using first $10 \mathrm{ml} 0.5 \mathrm{M} \mathrm{NaOH}$ in methanol for $10 \mathrm{~min}$ at $90{ }^{\circ} \mathrm{C}$ followed by $10 \mathrm{ml} 14 \% \mathrm{BF}_{3}$ in methanol (Sigma) for $10 \mathrm{~min}$ at $90{ }^{\circ} \mathrm{C}$ (Park \& Goins, 1994). FAMEs were recovered with hexane. Prior to GLC analysis, samples were dried over $0.5 \mathrm{~g}$ anhydrous sodium sulphate for $1 \mathrm{~h}$ and stored at $-20{ }^{\circ} \mathrm{C}$. FAMEs were separated by GLC (Varian 3400 instrument fitted with a flame-ionization detector) using a Chrompack CP Sil 88 column $(100 \mathrm{~m} \times 0.25 \mathrm{~mm}$ i.d., $0.20 \mu \mathrm{m}$ film thickness) and helium as carrier gas. The column oven temperature was initially held at $80{ }^{\circ} \mathrm{C}$ for $8 \mathrm{~min}$, and then increased at $8.5^{\circ} \mathrm{C}$ $\min ^{-1}$ to a final temperature of $200{ }^{\circ} \mathrm{C}$. The injection volume was $0.6 \mu \mathrm{l}$ with automatic sample injection on a SPI 1093 splitless oncolumn temperature programmable injector. Data were recorded and analysed on a Minichrom PC system (VG Data Systems). Peaks were identified with reference to retention times of fatty acids in a standard mixture. The percentage of individual fatty acids was calculated according to the peak area relative to the total area (total fatty acids were set at $100 \%)$. Results are shown as mean \pm SEM g per $100 \mathrm{~g}$ FAMEs.
Statistical analysis. Data are presented as means \pm SEM per group of mice. Data were analysed using analysis of variance (ANOVA) followed by Tukey's post-hoc test using GraphPad InStat version 3.05.

\section{RESULTS}

\section{Microbial production of $t 10, c 12$ CLA by recombinant $L$. paracasei NFBC 338 (Lb338)}

Lb338 harbouring the nisin-inducible Lactobacillus plasmid containing the coPAI gene, pEcoPAIL (Fig. 1), converted approximately $30 \%$ of linoleic acid to t10,c12 CLA, following induction at $\mathrm{OD}_{600} 0.5$ with $50 \mathrm{ng}$ nisin $\mathrm{ml}^{-1}$ and incubation for $48 \mathrm{~h}$ in the presence of the free fatty acid substrate $\left(0.5 \mathrm{mg} \mathrm{ml}^{-1}\right)$. However, t10, c12 CLA production by uninduced cells of Lb338 pEcoPAIL was similar to that obtained with nisin-induced cells $(24.4 \pm 0.4 \%$ and $28.9 \pm 0.5 \%$ conversion of substrate to product, respectively). Lb338 transformed with the empty vector pMSP3535 did not convert any of the added linoleic acid to $t 10, c 12$ CLA.

\section{Survival and gastric transit of administered lactobacilli and confirmation of ability to produce t10, c12 CLA following gastric transit}

Quantification of the numbers of bacteria of the recombinant CLA-producing Lb338 (group A) and the non-CLAproducing isogenic control Lb338 (group B) monitored in the faeces of mice confirmed gastrointestinal transit and survival of the administered strains. Stool recovery of the recombinant CLA-producing Lb338 and the non-CLAproducing isogenic control Lb338 was approximately $1 \times 10^{7}$ c.f.u. (g faeces) ${ }^{-1}$ at week 2 , which increased to approximately $1 \times 10^{8}$ c.f.u. (g faeces) $)^{-1}$ at week 4 and remained at $\sim 1 \times 10^{8}$ c.f.u. (g faeces) ${ }^{-1}$ throughout the rest of the trial. Recovered Lactobacillus isolates (from groups A and B) were inoculated into MRS broth containing linoleic acid $\left(0.5 \mathrm{mg} \mathrm{ml}^{-1}\right)$, which confirmed that the recovered Lb338 from group A, but not from group B, retained the ability to convert linoleic acid to $t 10, c 12$ CLA following passage through the gastrointestinal tract (data not shown).

Oral administration of the recombinant CLA-producing Lb338 (group A) and the non-CLA-producing isogenic control Lb338 (group B) did not significantly influence body weight gain throughout the feeding trial (Fig. 2). In addition, liver weights were not significantly different between the groups (data not shown).

\section{In vivo production of $t 10, c 12$ CLA by recombinant lactobacilli in mice}

Following 8 weeks of dietary treatment, it was demonstrated that $t 10, c 12$ CLA was produced by the recombinant Lb338 in the gastrointestinal tract of mice. The mean $t 10$, c12 CLA content of the adipose tissue was 4-fold higher in the mice that received the recombinant CLA-producing 


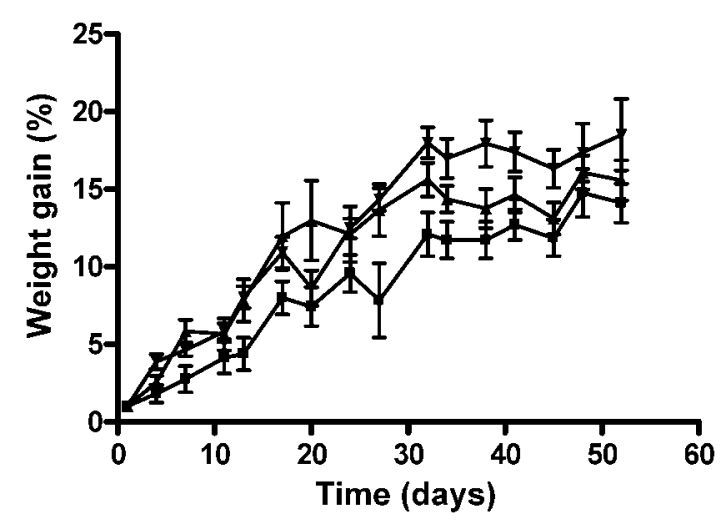

Fig. 2. Percentage body weight gain of mice fed $t 10, c 12$ CLAproducing recombinant $\mathrm{Lb} 338$ in combination with linoleic acid $(2 \%, w / w)$ (group $A, n=8 ; \boldsymbol{\square})$, isogenic control strain in combination with linoleic acid $(2 \%, \mathrm{w} / \mathrm{w})$ (group $\mathrm{B}, n=8 ; \boldsymbol{\Delta})$ and linoleic acid alone $(2 \%, w / w)$ (group $C, n=5 ; \boldsymbol{\nabla})$. Initial body weights: group A, $24.7 \pm 0.3 \mathrm{~g}$; group $B, 24.5 \pm 0.5$ g; group $C$, $24.9 \pm 0.5 \mathrm{~g}$. There were no significant differences between the groups.

Lb338 in combination with linoleic acid (group A) compared with the isogenic control (group B) $(P<0.001$, Fig. 3). This higher concentration of $t 10, c 12$ CLA in group A coincided with an approximately $20 \%$ lower concentration of linoleic acid in the adipose tissue (although the difference was not statistically significant) in comparison to group B (Table 2). Oral administration of the recombinant CLA-producing Lb338 (group A) also resulted in a 2.5-fold higher concentration of $t 10, c 12$ CLA in the livers compared with group B (non-CLA-producing Lb338),

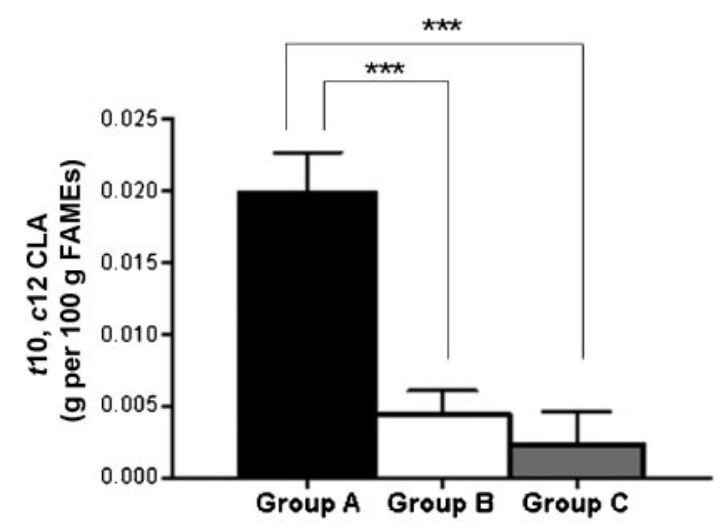

Fig. 3. $t 10, c 12$ CLA concentration of adipose tissue following 8 weeks supplementation. Group A: t10, c12 CLA-producing recombinant Lb338 in combination with linoleic acid $(2 \%, w / w)$ $(n=8)$. Group B: isogenic control strain in combination with linoleic acid $(2 \%, w / w)(n=8)$. Group C: linoleic acid alone $(2 \%, w / w)$ $(n=5)$. Statistical significance was determined by ANOVA followed by Tukey's post hoc test; ${ }^{\star * \star} P<0.001$.

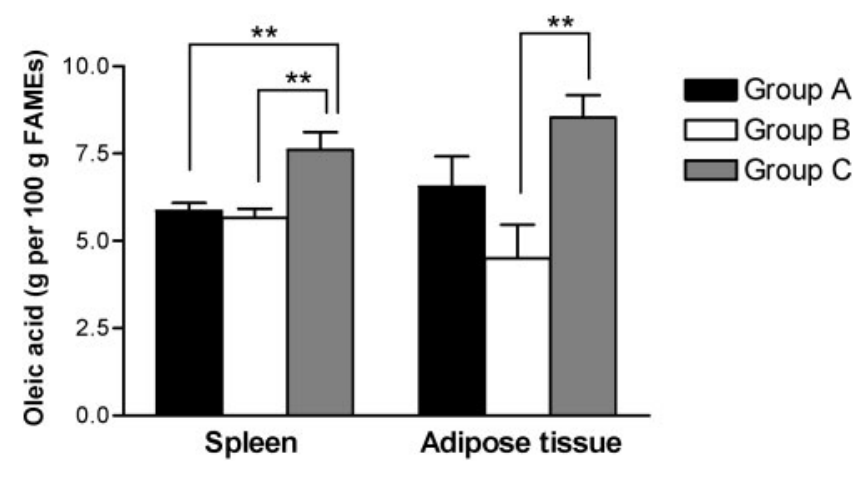

Fig. 4. Oleic acid concentrations in murine spleen and adipose tissue. Group A: $t 10, c 12$ CLA-producing recombinant Lb338 in combination with linoleic acid $(2 \%, w / w)(n=8)$. Group B: isogenic control strain in combination with linoleic acid $(2 \%, \mathrm{w} /$ w) $(n=8)$. Group C: linoleic acid alone $(2 \%, w / w)(n=5)$. Statistical significance was determined by ANOVA followed by Tukey's post hoc test; ${ }^{\star \star} P<0.01$.

although the difference was not statistically significant (Table 1).

\section{Dietary supplementation with probiotic Lb338 changes host tissue fatty acid composition}

Changes in tissue fatty acid composition caused by dietary supplementation with the probiotic Lb338 were investigated by comparing the groups of mice that received Lb338 (groups A and B) with the group that received linoleic acid alone (group C).

The mice that received Lb338 (groups A and B) had a significantly lower concentration of oleic acid in the spleen $(P<0.01)$ and a numerically lower concentration of oleic acid in the adipose tissue compared to mice that received linoleic acid alone (Fig. 4). Furthermore, administration of Lb338 (groups A and B) resulted in lower concentrations of arachidonic acid in the liver (17\% and $19 \%$, lower, respectively) compared to mice that received linoleic acid alone (group C), although the differences were not statistically significant (Table 1).

\section{DISCUSSION}

This study demonstrates that $t 10, c 12$ CLA production occurred in vivo when a recombinant Lactobacillus strain harbouring the gene encoding linoleic acid isomerase was administered to mice. As a direct consequence of this, the t10, c12 CLA content of adipose tissue was elevated fourfold in animals that received the recombinant $t 10, c 12$ CLA-producing Lb338 in combination with linoleic acid compared to mice that received the isogenic control strain. $t 10, c 12$ CLA has been shown to be beneficial to host health (Kim et al., 2002a; Ochoa et al., 2004; Yamasaki et al., 
Table 1. Fatty acid composition (\%) of livers from BALB/c mice

Data are means $( \pm \mathrm{SEM})$ (group A and group $\mathrm{B}, n=8$; group $\mathrm{C}, n=5$ ). Different superscript letters within a row indicate significant difference at $P<0.05$ based on ANOVA followed by Tukey's post-hoc test.

\begin{tabular}{|c|c|c|c|}
\hline \multirow[t]{2}{*}{ Fatty acid ${ }^{*}$} & \multicolumn{3}{|c|}{ Fatty acid composition ( $g$ per $100 \mathrm{~g}$ FAMEs) } \\
\hline & Group A (Lb338 + linoleic acid) & $\begin{array}{c}\text { Group B (isogenic control } \\
\text { strain + linoleic acid) }\end{array}$ & Group C (linoleic acid) \\
\hline $14: 0$ & $1.7(0.26)^{b, c}$ & $0.55(0.26)^{a}$ & $0.29(0.03)^{a}$ \\
\hline $16: 0$ & $17.82(0.80)$ & $18.30(0.42)$ & $19.5(0.58)$ \\
\hline $16: 1 \mathrm{c} 9$ & $0.8(0.08)$ & $0.8(0.06)$ & $0.67(0.04)$ \\
\hline $18: 2 \mathrm{n}-6$ & $30.89(2.07)$ & $31.40(4.02)$ & $28.38(0.46)$ \\
\hline $18: 3 n-3$ & $1.02(0.68)$ & $0.38(0.04)$ & $0.3(0.02)$ \\
\hline $18: 3 n-6$ & $0.69(0.09)$ & $0.68(0.06)$ & $0.51(0.03)$ \\
\hline$t 10, c 12$ CLA & $0.010(0.003)$ & $0.004(0.001)$ & $0.006(0.003)$ \\
\hline $18: 4 n-3$ & $0.41(0.03)$ & $0.51(0.06)$ & $0.38(0.02)$ \\
\hline $22: 6 n-3$ & $4.91(0.20)^{c}$ & $5.17(0.34)$ & $6.17(0.13)^{a}$ \\
\hline
\end{tabular}

${ }^{\star} 14: 0$, myristic acid; $16: 0$, palmitic acid; $16: 1 \mathrm{c} 9$, palmitoleic acid; $18: 0$, stearic acid; $18: 1 \mathrm{c} 9$, oleic acid; $18: 2 \mathrm{n}-6$, linoleic acid; $18: 3 \mathrm{n}-3$, linolenic acid; $18: 3 n-6$, $\gamma$-linolenic acid; $18: 4 n-3$, stearidonic acid; $20: 3 n-6$, dihomo- $\gamma$-linolenic acid; $20: 4 n-6$, arachidonic acid; $20: 5 n-3$, eicosapentaenoic acid; $22: 5 n-3$, docosapentaenoic acid; $22: 6 n-3$ docosahexaenoic acid.

2003) and has been demonstrated to alter body composition by reducing the fat content and increasing the lean body mass in animal studies, and also in some human studies (Blankson et al., 2000; Smedman \& Vessby, 2001; Thom et al., 2001). It was reported by Lee et al. (2006a) that $t 10, c 12$ CLA was produced in vivo when the humanoriginated bacterium L. rhamnosus PL60 was fed to dietinduced obese mice. The relatively low amount of $t 10, c 12$ CLA produced by this strain $\left(1.9 \mu \mathrm{g} \mathrm{ml}^{-1}\right.$ was detected in the sera) was enough to produce an anti-obesity effect. Moreover, liver steatosis, a well-known side effect of $t 10$, c12 CLA, was not observed following L. rhamnosus PL60 treatment in this study (Lee et al., 2006a). Thus, the lower dose of CLA produced by a probiotic strain may be a reliable solution to control the adverse effects caused by dietary $t 10, c 12$ CLA, i.e. liver steatosis. In addition, we have previously shown that the microbially derived $t 10, c 12$ CLA, at a concentration of $20 \mu \mathrm{g} \mathrm{ml}^{-1}$, has the ability to kill $92 \%$ of human SW480 colon cancer cells when coincubated with these cells for 5 days (Rosberg-Cody et al., 2007). In contrast to dietary CLA, which is primarily absorbed from the small intestine, using a t10, c12 CLAproducing strain would result in the provision of $t 10, c 12$ CLA directly and continuously to the large intestinal lumen, where this fatty acid would exhibit anti-inflammatory and anti-proliferative effects on colonocytes (Bassaganya-Riera et al., 2004; Kemp et al., 2003), thereby contributing to colonic mucosal homeostasis.
Although the $t 10, c 12$ CLA content of adipose tissue was significantly higher in the animals that received the $t 10, c 12$ CLA-producing recombinant strain, lower concentrations of $t 10, c 12$ CLA was also detected in animals that did not receive this strain. One possible explanation for this may be that the natural enteric microbiota of mice can produce some $t 10, c 12$ CLA, using linoleic acid as substrate. In this respect, it is worth noting that the origin of the PAI gene used in this study to transform Lb338 is Propionibacterium acnes, a strain that was originally isolated from mouse caecum (Verhulst et al., 1987).

Interestingly, administration of $L$. paracasei NFBC 338 (both the recombinant strain and the isogenic control) in combination with linoleic acid resulted in lower concentrations of arachidonic acid in the liver $(17 \%$ and $19 \%$ lower, respectively) compared to mice that received linoleic acid alone. Since the eicosanoids derived from arachidonic acid, such as the 2-series prostaglandins and the 4-series leukotrienes, are in general regarded as being proinflammatory in nature (Bagga et al., 2003), decreased amounts of arachidonic acid would be considered beneficial, especially in chronic inflammatory settings that are of high prevalence in Western societies such as inflammatory bowel disease, cardiovascular disease and obesity, which are characterized by an excessive production of arachidonic-acid-derived eicosanoids (Calder, 2001; James et al., 2000; Jupp et al., 2007; Wallace, 2001). Administration of $L$. paracasei NFBC 338 also resulted in 
Table 2. Fatty acid composition (\%) of adipose tissue from BALB/c mice

Data are means ( \pm SEM) (group A and group B, $n=8$; group C, $n=5$ ). Different superscript numbers within a row indicate significant difference at $P<0.05$ based on ANOVA followed by Tukey's post hoc test. ND, not detectable.

\begin{tabular}{|c|c|c|c|}
\hline \multirow[t]{2}{*}{ Fatty acid ${ }^{*}$} & \multicolumn{3}{|c|}{ Fatty acid composition (g per 100 g FAMEs) } \\
\hline & Group A (Lb338 + linoleic acid) & $\begin{array}{c}\text { Group B (isogenic control } \\
\text { strain + linoleic acid) }\end{array}$ & Group C (linoleic acid) \\
\hline $14: 0$ & $2.0(0.2)$ & $1.39(0.2)$ & $1.9(0.31)$ \\
\hline $16: 0$ & $23.04(0.59)$ & $21.73(1.12)$ & $22.42(0.53)$ \\
\hline $16: 1 \mathrm{c} 9$ & $0.89(0.54)$ & $1.24(0.38)$ & $1.08(0.34)$ \\
\hline $18: 0$ & $16.43(0.75)$ & $13.43(1.69)$ & $14.76(0.93)$ \\
\hline $18: 2 \mathrm{n}-6$ & $22.4(1.26)$ & $26.88(2.65)$ & $25.1(1.5)$ \\
\hline $18: 3 n-3$ & $0.13(0.007)$ & $0.13(0.007)$ & $0.15(0.04)$ \\
\hline $18: 3 n-6$ & $0.23(0.01)$ & $0.21(0.03)$ & $0.26(0.05)$ \\
\hline $18: 4 n-3$ & $0.07(0.02)^{c}$ & $0.03(0.007)^{b}$ & $\mathrm{ND}^{a}$ \\
\hline $20: 3 n-6$ & $0.12(0.01)$ & $0.10(0.01)$ & $0.11(0.01)$ \\
\hline $20: 4 n-6$ & $18.82(0.92)$ & $15.65(2.69)$ & $17.68(1.28)$ \\
\hline $20: 5 n-3$ & $0.07(0.001)$ & $0.08(0.007)$ & $0.06(0.004)$ \\
\hline $22: 5 n-3$ & $0.29(0.01)$ & $0.26(0.04)$ & $0.31(0.03)$ \\
\hline $22: 6 n-3$ & $1.4(0.06)$ & $1.2(0.2)$ & $1.33(0.13)$ \\
\hline
\end{tabular}

${ }^{*}$ See Table 1 for full names of fatty acids.

significantly lower concentrations of oleic acid in the spleen and adipose tissue compared to mice that received linoleic acid alone. Furthermore, our data indicate that it was not the linoleic acid isomerase gene, but the administered probiotic lactobacilli that was responsible for the decreased oleic acid observed in probiotic-supplemented animals compared with unsupplemented controls. Previously, Kalavathy et al. (2006) reported that administration of a mixture of Lactobacillus to broiler chickens significantly reduced the concentrations of oleic acid in liver and muscle. A reduced concentration of oleic acid has also been observed in the liver of rats fed a mixture of probiotics (Fukushima et al., 1999). This lower concentration of oleic acid could possibly be due to a reduction in the synthesis of the fatty acid or a reduced absorption from the intestine.

In conclusion, this is to our knowledge the first report to demonstrate that oral administration of a genetically modified $t 10, c 12$ CLA-producing strain (containing the single gene for $t 10, c 12$ CLA production) results in modulation of the fatty acid composition of the host, including significantly higher concentrations of $t 10, c 12$ CLA in adipose tissue, which is directly attributable to the presence of the linoleic acid isomerase gene.

\section{ACKNOWLEDGEMENTS}

The support of BASF Plant Science GmbH is gratefully acknowledged, as is the technical assistance of Seamus Aherne, Lee Siggens, Grainne Hurley and Frances O'Brien. The authors are supported, in part, by Science Foundation Ireland, The European Union (Project QLK12002-02362), the Irish Ministry for Food and Agriculture, the Higher Education Authority and the Health Research Board of Ireland and the Irish Government under the National Development Plan 2000-2006.

\section{REFERENCES}

Bagga, D., Wang, L., Farias-Eisner, R., Glaspy, J. A. \& Reddy, S. T. (2003). Differential effects of prostaglandin derived from omega-6 and omega-3 polyunsaturated fatty acids on COX-2 expression and IL-6 secretion. Proc Natl Acad Sci U S A 100, 1751-1756.

Barrett, E., Ross, R. P., Fitzgerald, G. F. \& Stanton, C. (2007). Rapid screening method for analyzing the conjugated linoleic acid production capabilities of bacterial cultures. Appl Environ Microbiol 73, 2333-2337.

Bassaganya-Riera, J., Reynolds, K., Martino-Catt, S., Cui, Y., Hennighausen, L., Gonzalez, F., Rohrer, J., Benninghoff, A. U. \& Hontecillas, R. (2004). Activation of PPAR $\gamma$ and $\delta$ by conjugated linoleic acid mediates protection from experimental inflammatory bowel disease. Gastroenterology 127, 777-791.

Blankson, H., Stakkestad, J. A., Fagertun, H., Thom, E., Wadstein, J. \& Gudmundsen, O. (2000). Conjugated linoleic acid reduces body fat mass in overweight and obese humans. J Nutr 130, 29432948.

Bryan, E. M., Bae, T., Kleerebezem, M. \& Dunny, G. M. (2000). Improved vectors for nisin-controlled expression in gram-positive bacteria. Plasmid 44, 183-190.

Calder, P. C. (2001). Polyunsaturated fatty acids, inflammation, and immunity. Lipids 36, 1007-1024.

Cherian, G., Wu, A. \& Goeger, P. M. (2005). Maternal dietary conjugated linoleic acid alters hepatic triacylglycerol and tissue fatty acids in hatched chicks. Lipids 40, 131-136.

Cho, H. J., Kim, W. K., Jung, J. I., Kim, E. J., Lim, S. S., Kwon, D. Y. \& Park, J. H. (2005). Trans-10,cis-12, not cis-9,trans-11, conjugated linoleic acid decreases ErbB3 expression in HT-29 human colon cancer cells. World J Gastroenterol 11, 5142-5150.

Cho, H. J., Kim, E. J., Lim, S. S., Kim, M. K., Sung, M. K., Kim, J. S. \& Park, J. H. (2006). Trans-10,cis-12, not cis-9,trans-11, conjugated linoleic acid inhibits G1-S progression in HT-29 human colon cancer cells. J Nutr 136, 893-898. 
Coakley, M., Ross, R. P., Nordgren, M., Fitzgerald, G., Devery, R. \& Stanton, C. (2003). Conjugated linoleic acid biosynthesis by humanderived Bifidobacterium species. J Appl Microbiol 94, 138-145.

Dumas, M. E., Barton, R. H., Toye, A., Cloarec, O., Blancher, C., Rothwell, A., Fearnside, J., Tatoud, R., Blanc, V. \& other authors (2006). Metabolic profiling reveals a contribution of gut microbiota to fatty liver phenotype in insulin-resistant mice. Proc Natl Acad Sci U S A 103, 12511-12516.

Folch, J., Lees, M. \& Sloane Stanley, S. G. (1957). A simple method for the isolation and purification of total lipids from animal tissues. J Biol Chem 226, 497-509.

Fukushima, M., Yamada, A., Endo, T. \& Nakano, M. (1999). Effects of a mixture of organisms, Lactobacillus acidophilus or Streptococcus faecalis on delta- 6 desaturase activity in the livers of rats fed a fat and cholesterol-enriched diet. Nutrition 15, 373-378.

Hornung, E., Krueger, C., Pernstich, C., Gipmans, M., Porzel, A. \& Feussner, I. (2005). Production of $(10 E, 12 Z)$-conjugated linoleic acid in yeast and tobacco seeds. Biochim Biophys Acta 1738, 105-114.

James, M. J., Gibson, R. A. \& Cleland, L. G. (2000). Dietary polyunsaturated fatty acids and inflammatory mediator production. Am J Clin Nutr 71, 343S-348S.

Jensen, R. G. (2002). The composition of bovine milk lipids. J Dairy Sci 85, 295-350.

Jupp, J., Hillier, K., Elliott, D. H., Fine, D. R., Bateman, A. C., Johnson, P. A., Cazaly, A. M., Penrose, J. F. \& Sampson, A. P. (2007). Colonic expression of leukotriene-pathway enzymes in inflammatory bowel diseases. Inflamm Bowel Dis 13, 537-546.

Kalavathy, R., Abdullah, N., Jalaludin, S., Wong, C. V. L. \& Ho, Y. W. (2006). Effects of Lactobacillus feed supplementation on cholesterol, fat content and fatty acid composition of the liver, muscle and carcass of broiler chickens. Anim Res 55, 77-82.

Kemp, M. Q., Jeffy, B. D. \& Romagnolo, D. F. (2003). Conjugated linoleic acid inhibits cell proliferation through a p53-dependent mechanism: effects on the expression of G1-restriction points in breast and colon cancer cells. J Nutr 133, 3670-3677.

Kim, E. J., Holthuizen, P. E., Park, H. S., Ha, Y. L., Jung, K. C. \& Park, J. H. (2002a). Trans-10, cis-12-conjugated linoleic acid inhibits Caco2 colon cancer cell growth. Am J Physiol Gastrointest Liver Physiol 283, G357-G367.

Kim, Y. J., Liu, R. H., Rychlik, J. L. \& Russell, J. B. (2002b). The enrichment of a ruminal bacterium (Megasphaera elsdenii YJ-4) that produces the trans-10, cis-12 isomer of conjugated linoleic acid. J Appl Microbiol 92, 976-982.

Lee, H. Y., Park, J. H., Seok, S. H., Baek, M. W., Kim, D. J., Lee, K. E., Paek, K. S., Lee, Y. \& Park, J. H. (2006a). Human originated bacteria, Lactobacillus rhamnosus PL60, produce conjugated linoleic acid and show anti-obesity effects in diet-induced obese mice. Biochim Biophys Acta 1761, 736-744.

Lee, S. H., Yamaguschi, K., Kim, J. S., Eling, T. E., Safe, S., Park, Y. \& Baek, S. J. (2006b). Conjugated linoleic acid stimulates an antitumorigenic protein NAG-1 in an isomer specific manner. Carcinogenesis 27, 972-981.

Lee, K., Paek, K., Lee, H. Y., Park, J. H. \& Lee, Y. (2007). Antiobesity effect of trans-10, cis-12-conjugated linoleic acid-producing Lactobacillus plantarum PL62 on diet-induced obese mice. J Appl Microbiol 103, 1140-1146.

Luchansky, J. B., Muriana, P. M. \& Klaenhammer, T. M. (1988). Application of electroporation for transfer of plasmid DNA to Lactobacillus, Lactococcus, Leuconostoc, Listeria, Pediococcus, Bacillus, Staphylococcus, Enterococcus and Propionibacterium. Mol Microbiol 2, 637-646.
Marchesi, J. \& Shanahan, F. (2007). The normal intestinal microbiota. Curr Opin Infect Dis 20, 508-513.

Mougios, V., Matsakas, A., Petridou, A., Ring, S., Sagredos, A., Melissopoulou, A., Tsigilis, N. \& Nikolaidis, M. (2001). Effect of supplementation with conjugated linoleic acid on human serum lipids and body fat. J Nutr Biochem 12, 585-594.

Navarro, V., Miranda, J., Churruca, I., Fernández-Quintela, A., Rodríguez, V. M. \& Portillo, M. P. (2006). Effects of trans-10,cis-12 conjugated linoleic acid on body fat and serum lipids in young and adult hamsters. J Physiol Biochem 62, 81-87.

Ochoa, J. J., Farquharson, A. J., Grant, I., Moffat, L. E., Heys, S. D. \& Wahle, K. W. (2004). Conjugated linoleic acids (CLAs) decrease prostate cancer cell proliferation: different molecular mechanisms for cis-9, trans-11 and trans-12, cis-12 isomers. Carcinogenesis 25, 11851191.

Ostrowska, E., Muralitharan, M., Cross, R. F., Bauman, D. E. \& Dunshea, F. R. (1999). Dietary conjugated linoleic acids increase lean tissue and decrease fat deposition in growing pigs. J Nutr 129, 20372042.

Park, P. W. \& Goins, R. E. (1994). In situ preparation of fatty acid methyl esters for analysis of fatty acid composition in foods. J Food Sci 59, 1262-1266.

Park, Y., Albright, K. L., Liu, W., Storkson, J. M., Cook, M. E. \& Pariza, M. W. (1997). Effect of conjugated linoleic acid on body composition in mice. Lipids 32, 853-858.

Risérus, U., Berglund, L. \& Vessby, B. (2001). Conjugated linoleic acid (CLA) reduced abdominal adipose tissue in obese middle-aged men with signs of the metabolic syndrome: a randomised controlled trial. Int J Obes Relat Metab Disord 25, 1129-1135.

Rosberg-Cody, E., Ross, R. P., Hussey, S., Ryan, C. A., Murphy, B. P., Fitzgerald, G. F., Devery, R. \& Stanton, C. (2004). Mining the microbiota of the neonatal gastrointestinal tract for CLA-producing bifidobacteria. Appl Environ Microbiol 70, 4635-4641.

Rosberg-Cody, E., Johnson, M. C., Fitzgerald, G. F., Ross, R. P. \& Stanton, C. (2007). Heterologous expression of linoleic acid isomerase from Propionibacterium acnes and anti-proliferative activity of recombinant trans-10, cis-12 conjugated linoleic acid. Microbiology 153, 2483-2490.

Smedman, A. \& Vessby, B. (2001). Conjugated linoleic acid supplementation in humans - metabolic effects. Lipids 36, 773-781.

Thom, E., Wadstein, J. \& Gudmundsen, O. (2001). Conjugated linoleic acid reduces body fat in healthy exercising humans. J Int Med Res 29, 392-396.

Verhulst, A., Janssen, G., Parmentier, G. \& Eyssen, H. (1987). Isomerization of polyunsaturated long chain fatty acids by propionibacteria. Syst Appl Microbiol 9, 12-15.

Wall, R., Ross, R. P., Shanahan, F. L., O'Mahony, C., O'Mahony, M., Coakley, O., Hart, P., Lawlor, E. M., Quigley, B. \& other authors (2009). Metabolic activity of the enteric microbiota influences the fatty acid composition of murine and porcine liver and adipose tissues. Am J Clin Nutr 89, 1393-1401.

Wallace, J. L. (2001). Prostaglandin biology in inflammatory bowel disease. Gastroenterol Clin North Am 30, 971-980.

Wilks, M. (2007). Bacteria and early human development. Early Hum Dev 83, 165-170.

Yamasaki, M., Ikeda, A., Oji, M., Tanaka, Y., Hirao, A., Kasai, M., Iwata, T., Tachibana, H. \& Yamada, K. (2003). Modulation of body fat and serum leptin levels by dietary conjugated linoleic acid in SpragueDawley rats fed various fat level diets. Nutrition 19, 30-35.

Edited by: D. A. Mills 